\title{
A Review on Geotrichum Lipases: Production, Purification, Immobilization and Applications
}

\author{
R. R. Maldonado, ${ }^{\text {a, }}{ }^{*}$ D. B. Lopes, ${ }^{\text {b }}$ E. Aguiar-Oliveira, ${ }^{c}$ E. S. Kamimura, ${ }^{d}$ and G. A. Macedo ${ }^{b}$ \\ ${ }^{a}$ University of Campinas, Food Department, Technical College \\ of Campinas (COTUCA), University of Campinas, R. Jorge \\ de Figueiredo Corrêa, 735, Parque Taquaral, Postal Code: \\ 13.087-261, Campinas, São Paulo, Brazil \\ bUniversity of Campinas, Laboratory of Bioactive Compounds, \\ Food and Nutrition Department, Food Engineering Faculty, Cidade \\ Universitária ZeferinoVaz, s.n., Postal Code: 13083-862, Campinas, \\ São Paulo, Brazil \\ 'Exact Science and Technology Department, Santa Cruz \\ State University, R. Jorge Amado, km 16, Salobrinho, \\ Postal Code: 45.662-900, Ilhéus, Bahia, Brazil \\ 'University of São Paulo, Laboratory of Bioprocess, \\ doi: 10.15255/CABEQ.2016.907 \\ Food Engineering Department, Animal Husbrandy and \\ Food Engineering Faculty, Av. Duque de Caxias Norte, 225, \\ Campus USP, Postal Code: 13635-900, Pirassununga, São Paulo, Brazil \\ Review \\ Received: May 17, 2016 \\ Accepted: December 3, 2016
}

Lipases are enzymes produced from innumerous microorganisms, plants and animal cells. They catalyze reactions of different lipid sources. The Geotrichum fungi are good producers of lipases with high hydrolytic activity and specificity for unsaturated fatty acids. A great number of studies have reported the importance of lipase from this genus and described important fermentation parameters for the enzyme production, such as nutrients, temperature, $\mathrm{pH}$, inoculum, time of fermentation and others. Furthermore, different strategies have been used to purify and immobilize lipases from Geotrichum and innumerous applications are cited in different processes as polyunsaturated fatty acids enrichment, hydrolysis and esterification of fat and oils, synthesis of aromas, biodiesel, and many others. This review highlights fundamental aspects of the production, purification, characterization, immobilization, and the applications of lipases produced by the genus Geotrichum.

Key words:

characterization, fermentation, Geotrichum, immobilization, lipase, purification

\section{Introduction}

Enzymes are known due the extreme specificity that they present on their substrates. This characteristic results in high productivity, low energy costs, and low quantity of undesirable byproducts when enzymes are applied as biocatalysts in industrial processes. An ecofriendly appeal is obtained in the industrial process utilizing enzymes ${ }^{1,2}$.

Lipases (triacylglycerol acylhydrolases EC 3.1.1.3) are enzymes that catalyze the hydrolysis of triacylglycerol into fatty acids and glycerol, monoand diacylgylcerol at the water-lipid interface and the reversible reaction of lipids in non-aqueous solvents $^{3-5}$. The versatility of lipases allows applica-

\footnotetext{
* Corresponding author: ratafta@yahoo.com.br,
}

Phone/Fax: +551935219900 tions in reactions such as hydrolysis, esterification, interesterification and transesterification, alcoholysis, acidolysis and aminolysis. Several modern bioprocessesuse lipases, such as: biodiesel production ${ }^{6,7}$, food industry ${ }^{8,9}$, medicine $^{10,11}$, in pharmaceutical and cosmetic industries ${ }^{12,13}$, pretreatment of industrial wastewaters $^{14,15}$, detergents formulation ${ }^{16,17}$, and many others ${ }^{18}$.

Lipases can replace alkaline catalyzers in biodiesel production facilitating the glycerol recovery and the purification of fatty methyl esters. However, high cost and low stability of the enzyme in the presence of alcohol are the largest disadvantages in this case. Whole cell, recombinant methods, protein and metabolic engineering are promising options to increase lipase applications in the biofuel process$\mathrm{es}^{6,7}$. In the food industry, lipases can be utilized for oil enrichment, flavor synthesis, quality improve- 
ment in bread, dough and dairy products, fragrance development, structured lipids and antioxidants production, etc. ${ }^{8-9}$. Lipases are capable of hydrolyzing triacylglicerol which facilitates the removal of greasy material from wastewaters, reducing the damage to the environment ${ }^{14-15}$. Furthermore, some lipases have high stability and activity in alkaline mediums, which allows the application of this biocatalyst in different types of detergent ${ }^{16-17}$.

Lipases can be produced by different organisms, including animals, plants, and microorganisms, but only microbial lipases are commercially significant due to their higher production and greater variety. Filamentous fungi and yeasts are the most preferred sources for lipase production, since this enzyme is mostly described as extracellular, which facilitates its recovery from the fermented medium. Approximately $50 \%$ of commercial lipases are produced from yeast and filamentous fungi, and some genus are frequently cited as good lipase producers, such as: Aspergillus, Candida, Fusarium, Geotrichum, Mucor, Penicilium, Pseudomonas and Rhizopus, Rhodotorula, etc., ${ }^{4,19-23}$.

Geotrichum sp. is a group of dimorphic yeasts that can occur in cream-colored yeast-like and in white mould-like colonies. The genus is composed of 22 species (including 10 sp. nov.) and the ecology shows a rather unexpected degree of consistency given the large phylogenetic distances between the species, including a high degree of rDNA polymorphism $^{24-25}$.

Geotrichum is commonly related to the cheese ripening process, biodegrading of dyes, and lipase production ${ }^{24-26}$. It was undesirable in traditional cheese making until the 1970s because it can cause unstable slim or 'toad skin'. However, since the 1980s it has been used to reduce bitterness as well as to develop flavors (especially in Camembert cheese). In some cases, it shows an antagonist effect against Mucor spp. and Listeria monocytogenes, and it can contribute to the cheese ripening process via action of its proteases and lipases. These benefits depend on the morphotype and strain used ${ }^{24}$.

Geotrichum consumes lactate, but it rarely consumes sugars and has a lower salt-tolerance during its growth. It is known for proteolytic, peptiodolytic and lipolytic activities, and for the production of long-chain free fatty acids and fatty acids esters, which have a minor flavor importance in different cheeses. It grows well in $\mathrm{pH}$ of 2.5 to 8.1 and with low level of oxygen. Its excess can inhibit other microorganisms during the cheese ripening process; however, the low quantity of its spores causes a lower flavor complexity ${ }^{25}$.

Among them, Geotrichum candidum and $\mathrm{Ga}$ lactomyces geotrichum (the teleomorph state or sexual form) are the most common and studied spe- cies for lipase production. Lipases from Geotrichum candidum are known for their high specificity for unsaturated long chain fatty acids and esters, while lipases from Galactomyces geotrichum present specificity for other esters of long chain fatty acids and good stability regarding temperature, $\mathrm{pH}$ and organic solvents. These properties allow their utilization in different reactions utilizing various vegetable oils ${ }^{22,25,27-29}$. These microorganisms have been isolated from soil and plants ${ }^{29,30}$, dairy products ${ }^{31,32}$, rotten vegetables and fruits ${ }^{33}$, different infections ${ }^{34}$, and many other sources ${ }^{35}$.

This review is focused on Geotrichum lipases and their biotechnological applicability. The aim is to discuss the latest aspects related to their production, purification, characterization, immobilization and application. The databases utilized for this purpose were mainly: Science Direct, Wiley Online Library, Springer, Scielo and Taylor \& Francis Online, between January, 2014 and October, 2016.

\section{Production of Geotrichum spp. lipases}

Geotrichum sp. can be obtained from different natural sources and its cultivation can occur under the most variable conditions of: nutritional requirements (carbon, nitrogen and lipid sources), growth parameters $(\mathrm{pH}$, temperature, agitation and aeration), inoculum conditions, and bioreactor system. Table 1 presents a list of a few recently published papers about lipases produced by Geotrichum species. G. candidum is the most studied amongst the genus in relation to lipase production, but other strains also are related to different processes such as G. fragrans, G. siamensis sp. nov., G. phurueaensis and G. klebahnii ${ }^{36-38}$.

Different substrates have been studied lately in search for better lipase productivity and/or lower process $\operatorname{costs}^{39-64}$. Organic and inorganic nitrogen sources are frequently investigated for lipase production from G. candidum (Table 1). Peptone, yeast extracts and urea as organic nitrogen sources, and ammonium chloride, ammonium nitrate and sodium nitrate as inorganic nitrogen sources, are the most cited. The concentrations used vary greatly, but the range from 0.1 to $5.0 \% \mathrm{w} / \mathrm{w}$ is more commonly used, and organic sources are added in higher quantities than inorganic sources ${ }^{44-64}$. Concentrations (\% w/w) of: 5.0 of peptone; 2.0 of yeast extract and 0.1 of $\mathrm{NaNO}_{3}$ and 0.5 of $\mathrm{NH}_{4} \mathrm{NO}_{3}$ are commonly applied in the lipase production ${ }^{43-46,49,57}$; however, optimized studies about medium composition reduced or eliminated some nitrogen sources in the process. Burket et al. and Maldonado et al. showed that 3.58 $\% \mathrm{w} / \mathrm{w}$ of peptone is enough to obtain a high level of lipase activity from G. candidum. They demon- 
Table 1 -Different conditions for Geotrichum spp. lipase production

\begin{tabular}{|c|c|}
\hline Microbial source & Growth conditions \\
\hline $\begin{array}{l}\text { G. candidum (DBM } \\
4012,4013 \text { and } \\
4166) \text { and } G . \\
\text { ludwigii (DBM 48) }\end{array}$ & $\begin{array}{l}\text { Liquid inoculum / Urea and olive oil / shaken tubes / } \\
24 \mathrm{~h} / 30{ }^{\circ} \mathrm{C} / \text { Liquid inoculum / Peptone, glucose and } \\
\text { olive oil / shaken tubes / } 24 \mathrm{~h}, 30{ }^{\circ} \mathrm{C}\end{array}$ \\
\hline G. candidum 4013 & $\begin{array}{l}\text { Liquid inoculum / Peptone and glucose / shaken flasks } \\
30^{\circ} \mathrm{C} / 24 \mathrm{~h}\end{array}$ \\
\hline
\end{tabular}

\section{G. candidum}

G. candidum

(41 strains)

Geotrichum sp.

G. candidum

G. candidum

G. candidum

NRRLY 552

Geotrichum sp. and $G$. candidum NRRLY 552

G. candidum

Geotrichum sp.

Geotrichum like strain R59

G. candidum

G. candidum

G. candidum

NRRL Y-552

G. candidum

NRRLY 552

Geotrichum sp.

G. candidum penicillatum M2

G. candidum
Liquid inoculum / Peptone and yeast extract / shaken flasks, $150 \mathrm{rpm} / 30^{\circ} \mathrm{C} / 54 \mathrm{~h}$

Peptone, glucose and olive oil / shaken flasks, $120 \mathrm{rpm} / 30{ }^{\circ} \mathrm{C} / 48 \mathrm{~h}$

Liquid inoculum / Olive oil, citric acid and $\mathrm{NH}_{4} \mathrm{NO}_{3} /$ shaken flasks, $250 \mathrm{rpm} / 28^{\circ} \mathrm{C} / 72 \mathrm{~h}$

Liquid inoculum / Olive mill wastewater / bubble column and settler bioreactor / aeration of $0.5 \mathrm{vvm} / \mathrm{pH} 6.0 / 30^{\circ} \mathrm{C} / 72 \mathrm{~h}$.

Liquid inoculum / Peptone and soybean oil / airlift, $2.5 \quad 20.0 \mu \mathrm{mol} \mathrm{FFA} \mathrm{min}{ }^{-1} \mathrm{~mL}^{-1}$ (both vvm, and stirred tank reactor, $300 \mathrm{rpm} / \mathrm{pH}=7.0 / 30{ }^{\circ} \mathrm{C}$ bioreactors)

Solid inoculum / Corn steep liquor and soybean oil / shaken flasks and stirred tank and airlift reactors, 250 $\mathrm{rpm} /$ airlift, $1 \mathrm{vvm} / \mathrm{pH}=7.0 / 30^{\circ} \mathrm{C}$

Solid inoculum / Corn steep liquor and soybean oil / shaken flasks, $150 \mathrm{rpm} / \mathrm{pH}=6.0 / 30{ }^{\circ} \mathrm{C}$

Liquid inoculum / Ammonium, leucine and glucose / batch reactor, $850 \mathrm{rpm} / 25^{\circ} \mathrm{C} /$ aeration of $13 \mathrm{~L} \mathrm{~h}^{-1} / 185 \mathrm{~h}$

Ammonium nitrate, corn steep liquor and soybean oil / shaken flasks, $120 \mathrm{rpm} / 30^{\circ} \mathrm{C} / 8.25 \mathrm{~h}$

Urea and sucrose and treolin / shaken flasks / $\mathrm{pH}=6.0 / 30^{\circ} \mathrm{C} / 48 \mathrm{~h}$

Yeast extract, peptone and olive oil / shaken flasks / $30^{\circ} \mathrm{C} / 6$ days

Liquid inoculum / Yeast extract, peptone, glucose and palm olein / shaken flasks / $\mathrm{pH}=7.2 / 30^{\circ} \mathrm{C} / 54 \mathrm{~h}$

Solid inoculum / Yeast hydrolysate and soybean oil / shaken flasks, $250 \mathrm{rpm} /$ airlift, $1 \mathrm{vvm} / \mathrm{pH}=7.0 / 30{ }^{\circ} \mathrm{C}$

Solid inoculum / Peptone and soybean oil / stirred tank reactor, $250 \mathrm{rpm} / \mathrm{pH}=7.0 / 30{ }^{\circ} \mathrm{C}$

Solid inoculum / Corn steep liquor and soybean oil / shaken flasks, $150 \mathrm{rpm} / \mathrm{pH} 5.0$

Liquid inoculum / Yeast extract $\left(10 \mathrm{~g} \mathrm{~L}^{-1}\right)$, sunflower oil refining waste $\left(10 \mathrm{~mL} \mathrm{~L}^{-1}\right)$ and minerals / shaken flasks, $170 \mathrm{rpm}$

Liquid inoculum/ Soybean molasses (32-368 $\left.\mathrm{g} \mathrm{L}^{-1}\right)$ shaken flasks / pH $(2.16-3.84) / 21.6-38.4{ }^{\circ} \mathrm{C} / 130 \mathrm{rpm}$
- Extracellular DBM 4166.

$10 \mu \mathrm{mol} \mathrm{FFA} \mathrm{/} 10^{6}$ cells $\mathrm{min}^{-1}$

- Cell-bound DBM 48, 4012, 4166:

$\sim 3 \mu \mathrm{mol} \mathrm{FFA} \mathrm{/} 10^{6}$ cells $\mathrm{min}^{-1}$

- Extracellular: $9.76 \pm 0.93 \mu \mathrm{mol} p$-NP $\mathrm{min}^{-1} \mathrm{~g}^{-1}$ of protein

- Cell-bound: $0.083 \pm 0.006 \mu \mathrm{mol} p$-NP $\min ^{-1} \mathrm{~g}^{-1}$ of extract

3.66 g mycelium-bound lipase $\mathrm{L}^{-1} ; 22.59$ mmol FFA $\min ^{-1} \mathrm{~g}^{-1}$ dry mycelia and 510 mmol FFA $\min ^{-1} \mathrm{~g}^{-1}$ protein

- Extracellular: 16.250-131.250 $\mu \mathrm{mol}$ FFA $\mathrm{min}^{-1} \mathrm{~mL}^{-1}$

- Cell-bound: 2.500-40.000 umol FFA $\mathrm{min}^{-1} \mathrm{~mL}^{-1}$

$23.15 \mu \mathrm{mol} \mathrm{FFA} \mathrm{min}^{-1} \mathrm{~mL}^{-1}$

Better production in the bubble column / $28 \mu \mathrm{mol} \mathrm{FFA} \mathrm{min}^{-1} \mathrm{~mL}^{-1}(70 \mathrm{~h})$ Reference

Maximum activities of: $21 \mu \mathrm{mol}$ FFA $\mathrm{min}^{-1} \mathrm{~mL}^{-1}$ (optimized in shaken flasks $48 \mathrm{~h}$ ); $25.67 \mu \mathrm{mol}$ FFA $\mathrm{min}^{-1} \mathrm{~mL}^{-1}$ (airlift $-64 \mathrm{~h}$ ) and $16.9 \mu \mathrm{mol}$ FFA $\mathrm{min}^{-1} \mathrm{~mL}^{-1}$ (stirred tank reactor $-37 \mathrm{~h}$ )

- Geotrichum sp: $11.0 \mu \mathrm{mol}$ FFA $\mathrm{min}^{-1} \mathrm{~mL}^{-1}$ - G. candidum: $17.0 \mu \mathrm{mol}$ FFA $\mathrm{min}^{-1} \mathrm{~mL}^{-1}$

Maximum specific growth rate of $0.21 \mathrm{~h}^{-1}$ around $27 \mathrm{~h}$

$20.0 \mu \mathrm{mol}$ FFA $\mathrm{min}^{-1} \mathrm{~mL}^{-1}$

$146 \mu \mathrm{mol}$ FFA $\mathrm{min}^{-1} \mathrm{~mL}^{-1}$

$87.7 \mu \mathrm{mol} p$-NP $\min ^{-1} \mathrm{~mL}^{-1}$

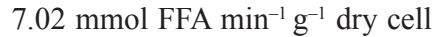

$-24.3 \mu \mathrm{mol}$ FFA $\mathrm{min}^{-1} \mathrm{~mL}^{-1}$ (optimized in shaken flasks - $48 \mathrm{~h}$ )

- 19.32 umol FFA min $^{-1} \mathrm{~mL}^{-1}$ (airlift $-32 \mathrm{~h})$

$16.0 \mu \mathrm{mol}$ FFA $\mathrm{min}^{-1} \mathrm{~mL}^{-1}$

$35.2 \mu \mathrm{mol}$ FFA $\min ^{-1} \mathrm{~mL}^{-1}$

Best cultivation after $48 \mathrm{~h}$ with a final $\mathrm{pH}$ of 6.0 which resulted in $0.6 \mu \mathrm{mol} \mathrm{FFA}$ $\mathrm{min}^{-1} \mathrm{~mL}^{-1}$ after medium centrifugation

12.0 $\mathrm{U} \mathrm{mL}^{-1}$ (optimized condition of $\mathrm{pH}=3.0,30{ }^{\circ} \mathrm{C}$ and $200 \mathrm{~g} \mathrm{~L}^{-1}$ of substrate

$* \mathrm{FFA}=$ free fatty acid; $p$-NP $=p$-nitrophenyl 
strated that sodium nitrate did not have a significant effect on the lipase activity ${ }^{52,61}$. Ginalska et al. showed that $0.4 \% \mathrm{w} / \mathrm{w}$ of urea was the best condition of nitrogen source for lipase production compared to other organic sources. They also showed that the use of only inorganic nitrogen sources had an inhibitory effect on lipase activity ${ }^{57}$.

The cost of these substrates is relatively high, and several studies have been conducted to find ways to replace these nitrogen sources with other cheaper sources. Corn steep liquor, yeast hydrolysate and soybean molasses are cited as good nitrogen sources due to their high concentration of nitrogen and amino acids. They have been used to replace the traditional nitrogen sources, maintaining or increasing lipase activity from Geotrichum. The used quantity of these sources varies greatly (3.0 $15.0 \% \mathrm{w} / \mathrm{w}$ ) according to the substrate and fermentation conditions ${ }^{53,54,56,60,62,64}$. These agro-industrial residues present a certain quantity of salts and their use eliminated the necessity of supplementing the medium with inorganic salts.

The addition of lipids substrates is a known strategy to increase the lipase activity for different microorganisms. Long-chain fatty acids have been used as inductors for lipase production from Geotrichum. Shimada et al., 1992, demonstrated that the use of unsaturated fatty acids (especially C 18:1, 18:2 and 18:3) results in high level of lipase activity in comparison to other fatty acids ${ }^{43}$. Several other studies had successful results utilizing vegetable lipids sources as inductors for lipase production from G. candidum. Some examples are babassu, cottonseed, fish, olive, soybean oils; almond, coconut, ginger, groundnut Jatropha, niger seed oil cakes, palm and sunflower effluents, and many others $^{39-64}$. Olive oil contains a high concentration of C18:1 unsaturated fatty acid, and innumerous studies indicate the use of this oil as an inductor for lipase production ${ }^{44,45,47-49,51,57,56}$. Soybean oil also shows similar results due to its similar composition to olive oil, and its low cost is a strong appeal for its application. Concentrations of $1.0 \% \mathrm{w} / \mathrm{w}$ are frequently utilized, but optimized studies showed that lower concentrations $(0.5$ to $0.7 \% \mathrm{w} / \mathrm{w})$ are enough to induce the lipase production, and concentrations above $1.0 \% \mathrm{w} / \mathrm{w}$ do not have significant effects on the increase in lipase activity ${ }^{52-54,56,60-62}$.

Glucose is the most used carbon source for the growth of $G$. candidum and the utilized concentration is usually $1.0 \% \mathrm{w} / \mathrm{w}$. Other carbon sources can be used, such as sucrose, galactose, lactose or lactic acid $^{44}$. A lipid source can be a carbon source and inductor simultaneously. In fact, glucose contributes to cellular growth but it can also reduce the lipase activity, as verified by Burkert et al. ${ }^{56}$.
The inoculum is another important variable in the lipase production from Geotrichum, and the liquid form $^{45,46}$, used at $10 \%(\mathrm{v} / \mathrm{v})^{47}$ or $5 \%(\mathrm{v} / \mathrm{v})^{48}$, is frequently applied. However, this type of inoculum can be an obstacle to the homogenization and standardization of inoculum, as shown by Resende-Maldonado et al. ${ }^{49}$ The authors proposed the utilization of an initial solid inoculum (with a specific area) followed by an intermediate liquid inoculum that reduced the variability of the lipase activity by 33 $\%$ during the fermentation. In another study, the use of intermediate liquid inoculum doubled the level of lipase activity compared to the use of the spore solution. The reduction in size of the inoculum by 10 to $2 \% \mathrm{v} / \mathrm{v}$ also increased the maximum lipase activity $^{59}$. This technique was applied with success in other studies with $G$. candidum and $G$. $\mathrm{sp}^{52-54,60-62}$ and it was verified that the lower quantity of solid inoculum increases the lipase activity. The reduction in the quantity of inoculum probably reduced the crowding effect (a typical mycological phenomenon that causes self-inhibition in spore fungus germination under crowded conditions). A similar technique for sampling solid cultures of $G$. candidum and $P$. camembertii was applied by Aldarf et al. ${ }^{50}$

In relation to the bioreactor choice, several studies have been conducted in shaken flasks (Table 1), but other types of bioreactors have also been applied successfully for Geotrichum cultivation; in general, the scale up from shaken flasks to a bioreactor system requires optimized cultivation conditions that can be achieved with the factorial designs methods ${ }^{49,51-54,65}$. The air lift bioreactor was successfully applied for lipase production from Geotrichum because the absence of mechanical agitation reduces the damage in the mycelium and provides better conditions for obtaining high lipase activity ${ }^{52,53,60}$. The use of a low rate of aeration also contributes to increasing lipase activity since $G$. candidum grows well with low levels of oxygen ${ }^{25}$. Studies in stirred tank bioreactor indicated that aeration of $1.0 \mathrm{vvm}$ or lower are the best conditions for lipase production from Geotrichum candidum ${ }^{51-53,60}$. The low level of oxygen is also efficient in shaken flasks; several studies have indicated agitation conditions below $200 \mathrm{rpm}$ for lipase production from Geotrichum, which reduces the quantity of dissolved oxygen $^{46,47,54,56,62-64}$.

Geotrichum is a mesophilic yeast and most studies have shown that temperatures near $30{ }^{\circ} \mathrm{C}$ are more appropriate for its growth and lipase production. The optimum $\mathrm{pH}$ for lipase production for this genus is around 7.0, but some species are able to produce lipases in more acidic ${ }^{62,64}$ or in more alkyne mediums ${ }^{42}$. In general, the $\mathrm{pH}$ increases during the fermentation time and at the end of fermentation it is possible to observe a great decrease 
in lipase levels, mostly due to the $\mathrm{pH}$ increase (above 8.0) or proteases activities ${ }^{53-56,60-62}$.

Lipases can be produced intra- (cell-bound) and/or extracellularly, as described by several authors ${ }^{41,44,46,48,66}$. The level of lipase activity and selectivity varies according to the location, strain and fermentation conditions. Hlavsová et $a .^{41}$ and Loo et al. $^{46}$ used a similar fermentation medium to produce cell-bound lipases, but in the first study the cell-bound lipase showed high selectivity for saturated fatty acids, while in the second study the highest selectivity was observed for polyunsaturated fatty acids, probably due to the difference in the strains used. In general, intracellular lipase production takes place in the initial hours of cultivation, followed by its release into the culture medium during the stationary phase when the highest levels of lipase are obtained ${ }^{41,66}$, although the duration of the stationary phase can vary greatly and the maximum lipase activity can occur from 24 to 96 hours, depending on fermentation conditions ${ }^{44,59}$.

Genetic engineering is very powerful and helpful in improving the enzyme expression. There are two ways to achieve this goal: Geotrichum species can be mutated to produce higher levels of lipases or Geotrichum genes for lipases can be expressed in bacteria. According to Cao et al. ${ }^{67}$ an increase of 53 $\%$ in biomass and an increase of $158 \%$ in lipid yield were obtained with the cultivation of a mutated strain of $G$. robustum. Mughal et al. ${ }^{65}$ obtained a lipase activity almost 24 times higher after inducing the mutagenesis of $G$. candidum. Yan et al. ${ }^{68}$ expressed G. candidum Y162 lipase genes in Pichia pastoris and obtained $55 \mathrm{U} \mathrm{mL}^{-1}$ of activity, and Pan et al. ${ }^{6}$, by expressing Geotrichum sp. lipase genes also in $P$. pastoris, obtained $(273 \pm 2.4) \mu \mathrm{mol}$ FFA $\mathrm{min}^{-1} \mathrm{~g}^{-1}$ of dry cells. In addition, Galactomyces geotrichum lipases have also been successfully expressed, mostly in Picchia pastoris ${ }^{28,70}$. In all these examples, the lipase activity or lipid contents in the clones or mutants of Geotrichum were much higher compared to original strains, indicating that these techniques can used successfully in industrial applications that need a high level of lipases activity. Furthermore, the clones or mutants were able to produce lipases that are more stable in high $\mathrm{pH}$ (above 8.0), high temperature (above $45^{\circ} \mathrm{C}$ ), and in different low polarity organic solvents, which normally does not occur with original strains of $\mathrm{Geo}$ trichum $^{28}$.

Lipase activity can be measured differently. The most common definition of $U$ (unit of lipase activity) is the amount of enzyme capable of releasing $1 \mu \mathrm{mol}$ of free fatty acids (FFA) per minute ${ }^{71}$ and its variations, such as, the amount of enzyme capable of releasing $1 \mathrm{mmol}$ of FFA per gram of dry cells $^{46}$ or the amount of enzyme that releases $1 \mu \mathrm{eq}$ of FFA per min per mg of dry cell ${ }^{72,73}$. Another defi- nition applied is the amount of enzyme capable of releasing $1 \mu \mathrm{mol}$ of $p$-nitrophenol ( $p$-NP) per min$u_{t e}{ }^{45}$. When comparing results from different authors, it is crucial to pay attention to these peculiarities. According to Table 1, the obtained range of lipase activities is wide, since the methods for cultivation and the methods for lipase activity determination also widely vary.

\section{Purification and characterization of Geotrichum spp. lipases}

Crude lipases preparations from different Geotrichum strains have been studied and characterized throughout the years. Different degrees of specificity, in relation to type and positions of fatty acids in triacylglycerols and fatty esters, different molecular weights, stability, and biochemical properties have been observed ${ }^{74-77}$. Innumerous methods for purification and characterization of these enzymes have also been applied, as presented in Table 2. The simple concentration (partial purification) applied mostly for extracellular lipases has been conducted by precipitation with acetone ${ }^{72}$, ethanol ${ }^{77}$ and ammonium sulphate ${ }^{79}$, ultrafiltration ${ }^{83}$, extraction by aqueous two-phase system ${ }^{84}$ and many other methods.

Among the precipitating agents, ammonium sulphate has been the most used ${ }^{45,58,78,79,86,88}$. Partial purification with this salt is easy to apply and results in high purification factors (in average $87 \%$ of recovery factor ${ }^{88}$ ); including situations with enzyme hyperactivation $^{78}$, which is very interesting for improving the recovery factors in the subsequent purification process. On the other hand, the total time of this method is long, since a long time is required for complete enzyme precipitation, and a dialysis step is necessary to remove the excess salt from the precipitate $^{78}$

In order to reduce the pre-purification time, other substances such as acetone ${ }^{45,63}$, ethanol ${ }^{78}$ and trichloroacetic acid ${ }^{80}$ were also applied. In these cases, pre-purifications were conducted with cold solvent to prevent denaturation of the lipases since most of these enzymes were not stable in the presence of organic solvents. Acetone has been cited as a good option to wash and activate whole cell lipases ${ }^{41,45}$, improving the catalytic activity. Ethanol resulted in a high concentration factor $(64-66)$ with short time processes $(1-2 \mathrm{~h})^{77,78}$, but the recovery factor was lower compared to ammonium sulphate precipitation because the lipases (in general) have low stability in contact with ethanol ${ }^{78}$.

Specific purification steps can be achieved by chromatographic techniques such as: ion exchange $\mathrm{e}^{58,63,70,72,75,77,79,83,86,88}$, hydrophobic interac- 
Table 2 -Purification and characterization of Geotrichum lipases

\begin{tabular}{r|l}
\hline Microbial source & \multicolumn{1}{c}{ Purification steps } \\
\hline G. candidum $4013 \begin{array}{l}\text { Acetone precipitation for the cell-bound } \\
\text { lipase; filtration and lyophylization for } \\
\text { extracellular lipase }\end{array}$ \\
G. candidum $4013 \begin{array}{l}\text { Ammonium sulphate precipitation (70\% } \\
\text { for the extracellular lipase, acetone for } \\
\text { the cell-bound lipase and acetone and } \\
\text { diethylether for the released lipase } \\
\text { (cell-bound) }\end{array}$
\end{tabular}

\section{G. candidum}

G. candidum penicillatum $\mathrm{M} 2$

Geotrichum-like Centrifugation to remove mycelium strain R59

\section{G. candidum (4012, 4013 \\ 4166) and \\ G. ludwigii (48)}

G. candidum NRRLY-552

Geotrichum sp. SYBC WU-3

Geotrichum sp. lipase expressed in $S$. cerevisiae

Filtration to remove mycelium and ammonium sulphate precipitation (70 \%) followed by anion exchange and two gel filtration chromatographyc steps / Purification:1.03-fold (precipitation), 4.36-fold (anion exchange), 5.74-fold and 7.76-fold (gel filtration)

Acetone precipitation $(4: 1=$ acetone:medium) / Ion exchange chromatography and hydrophobicinteractive chromatography / Purification factors of $1,1.15$ and 11.27 and yields (\%) of 100, 96 and 48, respectively

Extracellular lipase: filtration Cell-bound lipase: filtrated cells were resuspended in buffer

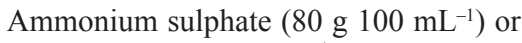
ethanol $\left(70 \mathrm{~mL} 100 \mathrm{~mL}^{-1}\right)$ precipitation; with or without lyophilization / The highes recovery factors (139\%) were obtained with ethanol precipitation and lyophilization (LE-1) / The highest concentration factors (64.6) were obtained with the salt precipitation and lyophilization (LS-1).

Ammonium sulphate precipitation (30-60\%) followed by ion exchange and gel filtration chromatography / Recovery of $11.2 \%(\mathrm{LipA})$ and $9.2 \%$ (LipB)

Surface displayed: cells were harvested, washed and resuspended;

Secretory lipase: purification by trichloroacetic acid (TCA) precipitation at $10 \%$

G. candidum 4013 Purification from the cell-free medium by matrixes with different hybrophobicity and desorption with Triton X-100 / Purification factors of 24.2 (Lip1), 6.1 (Lip2) and 1.2 (Lip3)

G. marinum ATCC 20614

Affinity and gel-filtration chromatography / 6 Purification factor of 56 and 76, and yield (\%) of $66 \%$ and $46 \%$, respectively

\begin{tabular}{l|l}
\multicolumn{1}{c|}{ Characterization $^{*}$} & Reference \\
\hline - Cell-bound: opt. $=35^{\circ} \mathrm{C}$ and $\mathrm{pH} 9.0 ;$ \\
low selectivity to the PUFA; \\
- Extracellular: opt. $=35^{\circ} \mathrm{C}$ and $\mathrm{pH} 8.5 ;$
\end{tabular}

higher selectivity

- Extracellular lipase: preference for $p$-NP decanoate (C10) and saturated triacylglycerols with $\mathrm{C} 12-\mathrm{C} 18$ and higher specificity with $\mathrm{C} 18: 2$ and short-chain esters; $\left(V_{\max } / K_{\mathrm{M}}\right)=0.015$ with $p$-NP C16

- Cell-bound lipase: preference for $p$-NP palmitate (C16) and triacylglycerols with acylgroup chain lengths between $\mathrm{C} 13-\mathrm{C} 16$ and short-chain esters; $\left(V_{\max } / K_{\mathrm{M}}\right)=0.085$

- Released cell-bound lipase: $\left(V_{\max } / K_{\mathrm{M}}\right)=0.117$

$32 \mathrm{kDa}$; opt. $=40^{\circ} \mathrm{C}$ and $\mathrm{pH} 7.0$; ions $\mathrm{Ca}$ and $\mathrm{Ba}$ enhanced activity; good stability at $30^{\circ} \mathrm{C} / 24 \mathrm{~h}$ at $\mathrm{pH}$ of 6.5 to 8.5

Good stability at $30-80{ }^{\circ} \mathrm{C}$; maximum activity at $50{ }^{\circ} \mathrm{C}$ and $\mathrm{pH} 9.0$;

Opt. $=\mathrm{pH} 7.0$ (with decreasing activity past $\mathrm{pH} 8.0$ ) and at $37^{\circ} \mathrm{C}$ and $50{ }^{\circ} \mathrm{C}$ (suggesting multiple forms); good stability at $60^{\circ} \mathrm{C}$ and at $\mathrm{pH} 6.5-8.0$

It was observed a great influence of medium composition growth on the enzymes. In the blackcurrant oil hydrolysis, the enzymes from 4012 and 4013 induced in medium A and 4166 and 4013 induced in medium $\mathrm{B}$ released unsaturated fatty acids.

At $37^{\circ} \mathrm{C}$, the lipases LS-1 and LE-1 presented reductions of $20 \%$ and $15 \%$ of its initial activities, respectively, after $6 \mathrm{~h}$ incubated in ethanol. In hexane, the reductions were around $40 \%$ in the first $12 \mathrm{~h}$.

- Lip A: $41.1 \mathrm{kDa}$; opt. $=20^{\circ} \mathrm{C}$ and $\mathrm{pH} 9.5$; preference for $\mathrm{C} 2$ to $\mathrm{C} 16$;

- Lip B: $35.8 \mathrm{kDa}$; opt. $=15^{\circ} \mathrm{C}$ and $\mathrm{pH}$ 9.5; preference for $\mathrm{C} 2$ and $\mathrm{C} 4$;

- Surface displayed lipase: opt. $=40{ }^{\circ} \mathrm{C}$ and $\mathrm{pH} 8.5$; maintained $89 \%$ of its original activity at $40{ }^{\circ} \mathrm{C} / \mathrm{pH}$ 8.5 / $3 \mathrm{~h}$; preference for $p$-NP caprylate (C8);

- Secretory lipase: opt. $=35^{\circ} \mathrm{C}$ and $\mathrm{pH} 8.5$; maintained $48 \%$ of its activity at $40{ }^{\circ} \mathrm{C} / \mathrm{pH} 8.5 / 3$ h; preference for $p$-NP caprylate (C8)

- Lip1: $70.5 \mathrm{kDa}$; preference for $p$-NP laurate (C12);

- Lip2: $75.5 \mathrm{kDa}$; preference for $p$-NP caprylato (C8);

- Lip3: $43 \mathrm{kDa}$; higher preference for C8 and ability for hydrolysis of racemic trans-2-(4-methoxybenzyl)1-cyclohexyl acetate

$62 \mathrm{kDa}$; opt. $=40^{\circ} \mathrm{C}$ and $\mathrm{pH} 8.0 ; K_{\mathrm{M}}=11.5 \mathrm{mmol} \mathrm{L}^{-1}$ and $V_{\text {max }}=1000 \mu \mathrm{mol} \mathrm{min}{ }^{-1} \mathrm{mg}^{-1}$ protein; preference for cis double bonds, like trilinolenin $(18: 3$ cis-9,12,15)

$* K_{\mathrm{M}}:$ Michaelis-Menten constant; $V_{\max }:$ Michaelis-Menten maximum velocity; $p$-NP $=p$-nitrophenyl; $\mathrm{PUFA}=$ polyunsaturated fatty acids 
tion $^{63,72,85,97}$, gel filtration ${ }^{58,79,82,86}$, metal-affinity ${ }^{74,87}$, etc. Many other techniques are possible for lipase purification $^{88}$.

Ion exchange is the most applied technique in purifying enzymes, and it is also applied to lipase purification as mentioned before. This type of purification is fast, easy to perform, requires low volume of sample solution, and is used for many other compounds. For lipase purification, ion exchange presents varied results for recovery factors $(5-80$ $\%)$, and for purification factor $(1.1$ - 33 fold $)$ $58,63,70,72,75,77,79,83,86$

Hydrophobic interaction chromatography is another interesting method for lipase purification since the lipases have good affinity to hydrophobic compounds. The recovery factors are normally high (48 - $96 \%$ ), and under optimized conditions high purification factors can be obtained, such as 86.7-fold, which was achieved under optimized conditions for purification lipase produced using yeast hydrolysate $^{97}$.

Several studies have shown the use of more than one purification technique in order to obtain high levels of purify. Ammonium sulphate precipitation combined with ion exchange and gel filtration resulted in a 7.76-fold purification ${ }^{58}$ and $11.2 \%$ of recovery factor ${ }^{79}$. A purification factor of 11.3 and $48 \%$ recovery were achieved with combined purification using acetone precipitation, ion exchange and hydrophobic interaction chromatography $^{63}$. In another study, it was possible to obtain relevant data regarding a large-scale purification of a $61.6 \mathrm{kDa}$ lipase from $G$. candidum with two consecutive chromatographic steps: ion exchange and hydrophobic interactions, resulting in a purification factor of 13.2 and a specific activity of $1.052 \mu \mathrm{mol}$ FFA min $^{-1} \mathrm{mg}^{-1}$ of protein ${ }^{89}$. Examples of combined methods have shown that a high level of purity can be obtained, but the recovery factors reduce with the increase in the number of purification steps due to the application of sequential methods improving enzymatic denaturation. The choice of the type and sequence of purification steps depends greatly on the properties of lipases and the potential applications for these enzymes.

Aspects related to optimum $\mathrm{pH}$ and temperature, stability, molecular weight, etc., vary according to the strain investigated and the medium composition applied. The characteristics are quite different from one lipase to another, but a few similarities can be observed among them. Literature cites that most of the values for optimum $\mathrm{pH}$ and temperature for lipase from Geotrichum vary between $6.0-7.0$ and $20-40{ }^{\circ} \mathrm{C}$, respectively ${ }^{28}$. Some studies indicate the optimum $\mathrm{pH}$ and/or optimum temperature is within these ranges ${ }^{58,72,77,78,86,90,95,97}$, however different results were obtained with modi- fications in several relevant factors for lipase production and purification, as shown in Table 2.

Genetic modifications, lipase location (cellbound or extracellular lipase), use of new strains and modifications in fermentation medium, etc., can cause drastic changes in lipase properties. A clone containing genes from Galactomyces geotrichum (a species less studied within the genus Geotrichum) produced high levels of lipase activity with high optimum $\mathrm{pH}(8.0)$, high stability $\mathrm{pH}$ (until $\mathrm{pH}=10.0$ ), and high optimum temperature $\left(50{ }^{\circ} \mathrm{C}\right)^{28}$. The cellbound lipase showed higher activity and higher stability than the extracellular lipase from the same strain in $\mathrm{pH}=8.5^{41}$ and the range of $\mathrm{pH}$ stability was wider (5.2-9.2) for mycelium lipase than extracellular lipase $(7.2-9.2)^{90}$. A new strain of Geotrichum sp. produced two new cold-adapted lipases, which showed optimum temperatures between 15 $20{ }^{\circ} \mathrm{C}$ despite the cultivation conditions at $30{ }^{\circ} \mathrm{C}^{79}$. A lipase with high optimum temperature $\left(47{ }^{\circ} \mathrm{C}\right)$ was obtained from Geotrichum candidum NRRLY-552 when clarified corn steep liquor was used as nitrogen source in fermentation medium ${ }^{97}$. The same strain exhibited an optimum temperature $10{ }^{\circ} \mathrm{C}$ lower when the microorganism was cultivated with yeast hydrolysate ${ }^{97}$ or peptone p2,61. $^{\text {. }}$

According to Sharma et al. ${ }^{4}$, most lipases obey Michaelis-Menten kinetics, and that is also valid for Geotrichum lipases as demonstrated in other studies ${ }^{45,82,97}$ for different strains and cultivation conditions. It has also been stated that Geotrichum lipases can present even four types of enzymes with different molecular weight and substrate specificities $^{91}$, but Baillargeon and $\mathrm{McCarthy}^{92}$, working with $G$. candidum NRRL Y-553, were able to obtain five glycosylated lipases with pI from 4.88 to 4.78 and with molecular weight also varying from 64 to $57 \mathrm{kDa}$. The isoelectric points of lipase from Geotrichum does not change much as do other parameters, and the results are normally in the range from 4.0 to $5.0^{77,83,86,89,92}$.

Geotrichum lipases are frequently cited by their substrate specificity for fatty acids having at least one $c i s-\Delta 9$ double bond ${ }^{70,74,89,90,92,94}$, but different catalytic specificities are found in different lipases from this genus ${ }^{93}$. A few examples are shown in Table 2, and it is important to highlight that some lipases from Geotrichum showed high specificity for saturated fatty acids ${ }^{41,74,76,90}$. This characteristic can be related to one of the most important habitats of this genus, which is dairy products containing a significant quantity of saturated fatty acids. Differences in the specificity were mentioned for the position of the chain in the tryacilglycerol. There are three types of lipases - 1,3-position ${ }^{72,76}$, 2-position ${ }^{91}$ and non-position specifics ${ }^{72,75,90}$. Sometimes the same microorganism produces different isolipases with different position specificities ${ }^{72}$. This is a great 
advantage because it allows application on different substrates.

Other examples can be cited to illustrate different possibilities regarding lipase properties: two lipases from $G$. candidum ATCC $66592^{94}$ presented different velocities of hydrolysis of palmitic acid methyl ester, the $61 \mathrm{kDa}$ lipase revealed a higher initial velocity compared to the $57 \mathrm{kDa}$ lipase. An extracellular Galactomyces geotrichum lipase, with $57 \mathrm{kDa}$ in the unglycosylate state and $62 \mathrm{kDa}$ as glycosylated, showed a similar specificity to $G$. candidum lipase but a different amino acid composition ${ }^{95}$.

Expressed Galactomyces geotrichum lipases have been also characterized, although less frequently than Geotrichum lipases. For example, Fernández et al..$^{70}$ purified $59 \mathrm{kDa}$ lipase from $G$. geotrichum BT107 expressed in P. pastoris LF163 by ultrafiltration and anion exchange chromatography, which yielded $97.5 \%$ and $42 \%$, respectively. Also, Yan et al. ${ }^{28}$, by expressing a $64 \mathrm{kDa}$ lipase from G. geotrichum Y05 in P. pastoris GS115 and pPIC9K, obtained 1.22-fold (ammonium sulphate precipitation), 2.8-fold (anion exchange chromatography), and 3.2-fold (gel filtration chromatography) purification. Additionally, Bertolini et al. ${ }^{96}$ expressed G. candidum lipases I and II in S. cerevisi$a e$, and significant differences between them were observed as lipase I presented much more affinity to long fatty acyl chains substrates than lipase II.

\section{Immobilization of Geotrichum spp. lipases}

Lipase has been successfully immobilized with different techniques ${ }^{98-101}$ and the same rules for general enzyme immobilization are also applied for Geotrichum lipase immobilization. It is common sense among researchers that there is no $100 \%$ perfect technique for it. All techniques will always present some disadvantages as well as advantages. A few examples of how Geotrichum lipases have been immobilized over the last years are presented in Table 3, and a few others examples will also be cited.

The entrapment of cells, instead of enzymes, seems to be a simple technique with good results for Geotrichum lipases. Pan et al. ${ }^{106}$ immobilized Geotrichum sp. G38 cells in silicon granules and obtained the same $\mathrm{pH}$ profile for both forms, free and immobilized, but an increase of $5{ }^{\circ} \mathrm{C}$ in optimum temperature after immobilization was observed. In addition, the glucose supplementation into the medium reaction - for the cells maintenance - contributed to increasing cycles of use from 23 to 28 with $90 \%$ activity. Bleve et al. ${ }^{107} \mathrm{immobi}-$ lized G. candidum cells in Ca-alginate beads, and
Carballeira et al. ${ }^{108}$ tested 6 different polymeric matrixes. In both cases, they were focused on other enzymes not lipases; Nakamura et al. ${ }^{109}$ also immobilized G. candidum IFO 4597 cells, but by adsorption onto the surface of a water-absorbing polymer $\left(\mathrm{BL}-100^{\circledR}\right)$, and applied it for stereo-selective oxidation and reduction in organic solvent.

Immobilization by adsorption is a simple technique with good results and is considered the most applied enzymatic immobilization technique ${ }^{110}$ even in combination with other techniques ${ }^{111}$. Two purified Geotrichum CMICC 335426 lipases, for example, were successfully adsorbed on hydrophobic macroporous polypropylene particles (Accurel EPI00) precoated with ovalbumin by Charton and Macrae ${ }^{112}$ and, according to their results, immobilization and the use of an organic media (tri- $n$-butylphosphate) did not have a major effect on the specificities of lipases A and B. However, for the immobilized lipase B, the hydrolysis of $20 \%$ of triolein presented a $v_{\max }$ value 357 times lower than the free lipase. The authors attributed this fact, among other reasons, to inactivation by the solvent.

Entrapment and adsorption can be simple techniques but they can also result in an undesirable leakage. For that purpose, the use of a stronger force, such as an ionic or covalent bond, can be of great help. As a brief example, Matsuda et al. ${ }^{113} \mathrm{im}-$ mobilized cells of $G$. candidum NBRC 5767 onto an ion exchange resin in order to use its alcohol dehydrogenase to reduce ketones.

Silica gel is a very common support for enzyme immobilization. It was used by Sonnet et al. ${ }^{114}$ to adsorb a commercial $G$. candidum lipase preparation. Bhattacharyya et al. ${ }^{115}$ also adsorbed carbonyl reductase from G. candidum NCIM 980 in silica gel, followed by cross-linking with glutaraldehyde for the immobilization. Several other materials, such as agriculture wastes ${ }^{116}$, membranes ${ }^{117}$ and ceramic materials ${ }^{118}$ have been proposed as a support for lipase immobilization in general, and the decision for the right support and technique should only be based on the process characteristics.

When an enzyme is produced attached to the cell membrane it is possible to consider that it is already immobilized, using the cell as its natural support ${ }^{44,48,69,76,80,119}$. In cases like these, the biomass can be easily removed from the reaction medium and used again in a new medium, avoiding several enzyme purification downstream steps.

\section{Applications of Geotrichum lipases}

In general, Geotrichum lipases have the same broad applicability like any other lipase, since this group of enzymes is the most investigated and in- 
Table 3 -Immobilization of Geotrichum lipases

\begin{tabular}{|c|c|c|c|}
\hline Microbial source & Technique / Matrix & Results* & Reference \\
\hline $\begin{array}{l}\text { G. candidum } \\
4013\end{array}$ & $\begin{array}{l}\text { Entrapment of cell bound lipase in calcium } \\
\text { alginate beads. }\end{array}$ & 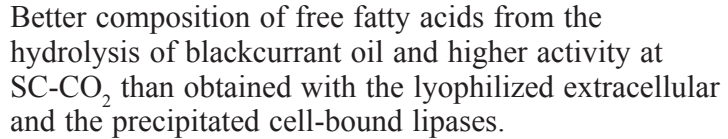 & 41 \\
\hline
\end{tabular}

$\begin{array}{ll}\text { G. candidum } & \text { The filtered enzymatic solution was } \\ \text { strain NRRL } & \text { immobilized onto mesoporous PHB } \\ \text { Y-552 } & \text { particles under continuous agitation } \\ & \text { (200 rpm) under room temperature for } \\ & \text { about } 12 \mathrm{~h} .\end{array}$

G. candidum NRRLY-552

Geotrichum sp.

Geotrichum sp. lipase gene expressed in

Pichia pastoris GS115
Entrapment in alginate beads, adsorption onto niobium-graphite particles, celite and zeolites.

Immobilization of the purified lipase onto NKA resin was conducted in four different medium: phosphate buffer $(\mathrm{pH}=8.0)$ (IMLA); the same aqueous buffer added of octane (IMLAO), fish oil (IMLAF) and oleic acid (IMLAOA). The IMLAOA was frozen and lyophilized, the others were just filtered.

The purified lipase powder aggregates were immobilized by cross-linking with glutaraldehyde with organic solvents (CLEA) and with polyethylenimine (PEI- CLEA).
Geotrichum sp.

Geotrichum sp. lipase gene expressed in

Pichia pastoris GS115
- PCMC methodology: lipase was dehydrated (in organic medium) on the surface of micro-crystals of $\mathrm{K}_{2} \mathrm{SO}_{4}$, coating them;

- CLPCMC methodology: the obtained crystals described above were crosslinked with glutaraldehyde.

The purified lipase was bioimprinted, $\mathrm{pH}$ tunned, salt activated, lecithin coated and adsorbed onto NKA, a macroporous resin.
The best immobilization yield $(81.2 \%)$ was obtained offering $1031.1 \mu \mathrm{mol} \mathrm{FFA} \mathrm{min}^{-1} \mathrm{~mL}^{-1}$ of initial enzymatic activity and the resultant biocatalyst presented a hydrolytic activity of $284.3 \mu \mathrm{mol} \mathrm{FFA} \mathrm{m^{-1 }}$ $\mathrm{g}^{-1}$ of support. The immobilized enzyme presented, at $\mathrm{pH} 8.0$, a maximum activity $\left(51.3 \mu \mathrm{mol}\right.$ FFA min $^{-1} \mathrm{~g}^{-1}$ of support) 1.5 times higher than the free enzyme. In relation to the optimum temperatures, the immobilization increased in $3{ }^{\circ} \mathrm{C}$ in relation to the free enzyme $\left(37^{\circ} \mathrm{C}\right)$.

Immobilization yield (\%) / immobilized activity ( $\mu$ mol FFA min $^{-1} \mathrm{~mL}^{-1}$ ): 65.7 / 14.8 (zeolite), 49.0 / 4.9 (niobium-graphite), $31.8 / 23.8$ (alginate) and $20.0 / 93.4$ (celite).

It was observed that the IMLAF and IMLAOA exhibited the highest fish oil hydrolysis degrees (around 35 and $40 \%$, respectively) in relation to the free lipase (around $10 \%$ ) and also a better thermal stability, with $60 \%$ of the relative hydrolysis degree at $45-55^{\circ} \mathrm{C}$. In addition, the two biocatalysts showed similar operational stability, remaining $80 \%$ of its relative hydrolysis degree after five cycles of repeated use.

Both techniques, CLEA and PEI-CLEA, avoided the pellet agglomeration and resulted in 33 and $42 \%$ of hydrolysis degree, respectively, contrasting to the $12 \%$ degree with the free enzyme. The PEI-CLEA biocatalyst also presented more thermal stability, better tolerance towards strong polar and non-polar organic solvents, no leakage of enzyme and better reusability after retaining $72 \%$ of its relative hydrolysis degree after 5 cycles of use.

PCMC and CLPCMC presented a biodiesel yield of 69 and $72 \%$ respectively; free lipase resulted in $29 \%$. CLPCMC also presented higher maintenance of activity after 5 successive batch reactions ( $80 \%$ ), better stability in $\mathrm{pH}$ from 4.0 to 6.0 and in temperatures from 45 to $50{ }^{\circ} \mathrm{C}$.

The biocatalyst obtained presented a 18.4-fold enhancement in its sterification activity towards metyloleate synthesis, a highly improved operational stability compared to the crude form and after 10 cycles of use it was capable of retaining $90 \%$ of its initial activity.

$* \mathrm{FFA}=$ free fatty acid

dustrially applied. Apparently, the majority of the Geotrichum lipases have a special characteristic that allows their utilization in different vegetable oil. They are very selective towards unsaturated long-chain fatty acids with cis-9 double bonds, such as oleic and linoleic acids, as mentioned before. Other applications can also be cited for these enzymes, as follows.

\section{Polyunsaturated fatty acids enrichment}

Polyunsaturated fatty acids (PUFA) are very important for different physiological functions ${ }^{120}$, thus, their enrichment in medium is of great interest and Geotrichum lipases can be perfectly applied for that purpose. Pan et al. ${ }^{69}$, when studying the enrichment of eicosapentaenoic (EPA) and docosahexae- 
noic (DHA) acids contents from fish oil, using a Geotrichum sp. lipase displayed on the P. pastoris wall, obtained an increase of about 1.2-fold for each acid, reaching $46.62 \%$ of total yield, for both. The best hydrolysis degree in fish oil for producing EPA and DHA was $40 \%$ in both cases, using immobilized lipase from Geotrichum sp. ${ }^{12}$ These results were about 2 and 4 times higher than with the use of free enzyme. In addition, $\gamma$-linolenic acid (GLA) was successfully enriched up to $40 \%$ in the acylglycerol fraction, when Fregolente et al. ${ }^{29}$ applied an enzymatic extract of $G$. candidum in borage oil, a 1.9-fold enrichment. Fogliaand Sonnet ${ }^{121}$, with silica immobilized and free lipases from G. candidum, resulted in up to $70 \%$ recovery of the same acid, GLA.

\section{Conjugated linoleic acid enrichment}

Conjugated linoleic acid (CLA) are C18 fatty acids mainly composed of cis-9, trans-11 isomers and are considered anti-carcinogenic, among other benefits, and are naturally found in many natural food sources, especially animal (ruminant) products ${ }^{122}$. A commercial $G$. candidum lipase preparation was applied by McNeil et al. ${ }^{123}$, with safflower oil, in order to enrich the composition of the cis-9, trans-11 and also the trans-10, cis-12 isomers. According to the authors, obtained was a maximum fraction of about $98 \%$ (between 13-35\% of conversion) of the cis-9, trans-11 in a much higher velocity. The same commercial enzyme preparation was also applied by Haas et al. ${ }^{124}$ besides the recombinant $P$. pastoris with the cis-9 selective B lipase gene of $G$. candidum CMICC 335426 expressed; both enzymes demonstrated a highly selective production of the cis-9 isomer with compositions of 77 and $94 \%$, respectively.

\section{Lipid hydrolysis}

Lipases are capable of catalyzing both hydrolysis and synthesis of esters, and their specificities vary from strain to strain as much as their hydrolytic yield in di- and monoacylglycerol, glycerol and free fatty acids. The hydrolysis of triacylglycerols of black currant oil was evaluated for three different strains of G. candidum and one of G. ludwigii by Stránský et al. ${ }^{76}$ and it was observed that the medium in which they were induced presented a great influence on the profile of the obtained hydrolyzed fatty acids. Diks and Lee ${ }^{125}$ evaluated the selective hydrolysis of sunflower oil by the wild G. candidum CMICC 335426 lipase B and the one expressed by P. pastoris aiming at the production of a very slightly saturated fatty acid oil in which obtained degrees of hydrolysis of around $60 \%(\mathrm{w} / \mathrm{w})$ with more than $99 \%(\mathrm{w} / \mathrm{w})$ of unsaturated compounds in free fatty acid fraction, using sunflower oil for the hydrolysis. Other examples of Geotrichum lipases application in hydrolysis are cited briefly in Table 2 as Brabcová et al. ${ }^{45,81}$ and Cai et al. ${ }^{79}$

\section{Synthesis of aroma compounds}

Lipids are an important source of aroma compounds ${ }^{126}$ and several Geotrichum strains are responsible, for example, for the characteristic aroma/ flavor of different cheese, not exclusively because of their lipases but also other enzymes produced during the ripening of cheeses ${ }^{127-129}$. In addition, according to Neto et al. ${ }^{130}$, hydrolyzed castor oil and its fatty acid derivatives proved to be effective precursors of $\gamma$-decalactone, responsible for a fruit/ chocolate aroma by the lipases from $G$. fragrans and Geotrichum sp. with the first lipase resulting in a better production $\left(600 \mathrm{mg} \mathrm{L}^{-1}\right)$. Macedo and Pastore $^{131}$ evaluated, among others, a lipase from Geotrichum sp. in order to produce aromatic esters, and this lipase was able to esterify all the substrates tested, resulting in, for example, $80 \%$ of esterification with butanol and acetic acid. Recently, Vong and $\mathrm{Liu}^{132}$ evaluated different strains of yeasts to reduce the undesirable flavor of okara (a soybean residue obtained during the production of soymilk). During the fermentation of okara using the G. candidum, these authors observed a significant reduction in hexanal and trans-2-hexane, which were converted mainly into 2-propanol and pentanoic acid.

\section{Conclusions}

According to this review, it is possible to see that there are different aspects regarding production, purification, immobilization, and application of lipase from Geotrichum genus. Production is carried out to obtain extracellular lipases (mainly) and cell bond lipases using different substrates, operating conditions and bioreactors. Most studies produce lipases using submerged fermentation, and in recent years many alternative nitrogen sources have been explored in order to reduce the cost of production. Organic nitrogen sources, lipids for the induction and as carbon source, and glucose for growth are the most typically applied substrates for lipase production from Geotrichum. The application of different substrates and conditions allow production of lipases with different biochemical characteristics. In addition, genetic modifications have been evaluated to increase the lipase production using different species of Geotrichum or by expressing their genes in other species like $P$. pastoris and S. cerevisiae, for example.

Purification has been studied through different techniques, such as precipitation using salt solutions or organic solvents, ultrafiltration, and different chromatographic techniques, especially employing hydrophobic systems. A great number of techniques 
have also been used to immobilize lipases from Geotrichum genus, especially adsorption in hydrophobic supports, entrapment using different supports, and in its own cell (natural support). Production, purification and immobilization processes can change the characteristics of lipases from Geotrichum drastically, however, most of the studies have shown that the lipases from this genus are good biocatalysts in $\mathrm{pH}$ near 7.0 and temperature near $30{ }^{\circ} \mathrm{C}$. These characteristics can be changed with genetic modifications, use of different strain, and different fermentation conditions.

Finally, different applications have been mentioned in the literature about the use of lipases from Geotrichum. The most important characteristic of lipases from this genus is the specificity from unsaturated long-chain fatty acids with cis-9 double bonds, extensively studied for a long time. Furthermore, other applications are frequently cited, such as enrichment of both polyunsatured fatty acids (PUFA) and conjugated linoleic acids, hydrolysis of lipids, and synthesis of aromas. All this information is of great value to increase the potential for Geotrichum lipases applicability.

\section{ACKNOWLEDGMENTS}

The authors would like to thank the Fundação de Amparo à Pesquisa do Estado de São Paulo (FAPESP, Brazil), the Conselho Nacional de Desenvolvimento Científico e Tecnológico (CNPq, Brazil) and the Coordenação de Aperfeiçoamento de Pessoal de Nivel Superior (CAPES, Brazil) for their financial support.

\section{References}

1. Contesini, F. J., Lopes, D. B., Macedo, G. A., Nascimento, M. G., Carvalho, P. O., Aspergillus sp. lipase: Potential biocatalyst for industrial use, J. Mol. Catal. B: Enz. 67 (2010) 163.

doi: https://doi.org/10.1016/j.molcatb.2010.07.021

2. Gog, A., Roman, M., Tosa, M., Paizs, C., Irimie, F. D., Biodiesel production using enzymatic transesterification: Current state and perspectives, Renew. Energy 39 (2012) 10. doi: https://doi.org/10.1016/j.renene.2011.08.007

3. Jaeger, K. E., Reetz, M. T., Microbial lipases form versatile tools for biotechnology, Trends. Biotechnol. 16 (1998) 396. doi: https://doi.org/10.1016/S0167-7799(98)01195-0

4. Sharma, R., Chisti, Y., Banerjee, U. C., Production, purification, characterization, and applications of lipase, Biotechnol. Adv. 19 (2001) 627. doi: https://doi.org/10.1016/S0734-9750(01)00086-6

5. Stergiou, P.-Y., Foukis, A., Filippou, M., Koukouritaki, M., Parapouli, M., Theodorou, L. G., Hatziloukas, E., Afendra, A., Pandey, A., Papamichael, E. M., Advances in lipase-catalyzed esterification reactions. Biotechnol. Adv. 31 (2013) 1846.

doi: https://doi.org/10.1016/j.biotechadv.2013.08.006
6. Fukuda, H., Kondo, A., Noda, H., Biodiesel fuel production by transesterification of oils, J. Biosc. Bioeng. 92(2001) 405. doi: https://doi.org/10.1016/S1389-1723(01)80288-7

7. Hwang, H. T., Qi, F., Yuan, C., Zhao, X., Ramkrishna, D., Liu, D., Varma, A., Lipase-Catalyzed Process for Biodiesel Production: Protein Engineering and Lipase Production, Biotechnol. Bioeng. 111 (2014) 639. doi: https://doi.org/10.1002/bit.25162

8. Aravindan, R., Anbumathi, P., Viruthagiri, T., Lipase applications in food industry, Ind. J. Biotechnol. 6 (2007) 141.

9. Ferreira-Dias, S., Sandoval, G., Plou, F., Valero, F., The potential use of lipases in the production of fatty acid derivatives for the food and nutraceutical industries, Electr. J. Biotechnol. 16 (2013).

doi: https://doi.org/10.2225/vol16-issue3-fulltext-5

10. Gopinath, S. C. B., Anbu, P., Lakshmipriya, T., Hilda, A. Strategies to characterize fungal lipases for applications in medicine and dairy industry., BioMed Res. Int. Article ID 154549 (2013). doi: https://doi.org/10.1155/2013/154549

11. Mo, X., Liu, X., Wang, L., Li, H., Lu, X., Huang, J., Chen, J., Cao, J., Li, J., Chen, S., Tang, Y., Peng, X., Gu, D., Lipoprotein lipase gene polymorphism rs1059611 functionally influences serum lipid concentrations, Atheroscl. 229 (2013) 511. doi: https://doi.org/10.1016/j.atherosclerosis.2013.05.005

12. Ansorge-Schumacher, M. B., Thum, O., Immobilised lipase in the cosmetics industry, Chem. Soc. Rev. 42 (2013) 6475. doi: https://doi.org/10.1039/C3CS35484A

13. Wang, P.-Y., Chen, Y.-J., Wu, A.-C., Lin, Y.-S., Kao, M.-F., Chen, J.-R., Ciou, J.-F., Tsai, S.-W., (R, S)-Azolides as novel substrates for lipase-catalyzed hydrolytic resolution in organic solvents, Adv. Synt. Catal. 351 (2009) 2333. doi: https://doi.org/10.1002/adsc.200900391

14. Jeganathan, J., Bassi, A., Nakhla, G., Pre-treatment of high oil and grease pet food industrial wastewaters using immobilized lipase hydrolyzation, J. Hazard. Mat. 137 (2006) 121.

doi: https://doi.org/10.1016/j.jhazmat.2005.11.106

15. Kim, S. J., Shoda, M., Decolorization of molasses by a new isolate of Geotrichum candidum in a jar fermentor, Biotechnol. Technol. 12 (1998) 497. doi: https://doi.org/ 10.1023/A:1008824119174

16. Aaslyng, D., Gormsen, E., Malmos, H., Mechanistic studies of proteases and lipases for the detergent industry, J. Chem. Technol. Biotechnol. 50 (1991) 321. doi: https://doi.org/10.1002/jctb.280500304

17. Li, X.-L., Zhang, W.-H., Wang, Y.-D., Dai, Y.-J., Zhang, H.T., Wang, Y., Wang, H.-K., Lu, F.-P., A high-detergent-performance, cold-adapted lipase from Pseudomonas stutzeri PS59 suitable for detergent formulation, J. Mol. Catal. B: Enz. 102 (2014) 16. doi: https://doi.org/10.1016/j.molcatb.2014.01.006

18. Batista, K. A., Purcena, L. L. A., Alves, G. L., Fernandes, $K$. F., A pectin-lipase derivative as alternative copolymer for lipase assay, J. Mol. Catal. B: Enz. 102 (2014) 25. doi: https://doi.org/10.1016/j.molcatb.2014.01.010

19. Carvalho, P. O., Calafatti, S. A., Marassi, M., Silva, D. M., Contesini, F. J., Bizaco, R., Macedo, G. A., Potencial de Biocatálise Enantiosseletiva de Lipases Microbianas, Quim. Nova. 28 (2005) 614. doi: https://doi.org/10.1590/S0100-40422005000400012 
20. Hita, H., Robles, A., Camacho, B., González, P. A., Esteban, L., Jiménez, M. J., Muñio, M. M., Molina, E., Production of structured triacylglycerols by acidolysis catalyzed by lipases immobilized in a packed bed reactor, Biochem. Eng. J. 46 (2009) 257. doi: https://doi.org/10.1016/j.bej.2009.05.015

21. Rapp, P., Bachaus, S., Formation of extracellular lipases by filamentous fungi, yeasts and bacteria, Enz. Microb. Technol. 14 (1992) 938

doi: https://doi.org/10.1016/0141-0229(92)90059-W

22. Treichel, H., Oliveira, D., Mazutti, M. A., Di Luccio, M., Oliveira, J. V., A review on microbial lipases production, Food Bioprocess. Technol. 3 (2010) 182. doi: https://doi.org/10.1007/s11947-009-0202-2

23. Vakhlu, J., Kour, A., Yeast lipases: enzyme purification, biochemical properties and gene cloning, Eletctr. J. Biotechnol. 9 (2006) 69. doi: https://doi.org/10.2225/vol9-issue1-fulltext-9

24. Alper, I., Frenette, M., Labrie, S., Ribosomal DNA polymorphisms in the yeast Geotrichum candidum, Fungal Biol. 115 (2011) 1259. doi: https://doi.org/ 10.1016/j.funbio.2011.09.002

25. Eliskases-Lechner, F., Yeasts and Molds: Geotrichum candidum; In: Encyclopedia of Dairy Sciences; $2^{\text {nd }}$ Ed., Academic Press, 2011, 765-771.

26. Jadhav, S. U., Kalmea, S. D., Govindwar, S. P., Biodegradation of Methyl red by Galactomyces geotrichum MTCC 1360, Int. Biodeter. Biodeg. 62 (2008) 135. doi: https://doi.org/10.1016/j.ibiod.2007.12.010

27. Phillips, A., Pretorius, G. H. J., van Rensburg, H. G., Molecular characterization of a Galactomyces geotrichum lipase, another member of the cholinesterase/lipase family, Biochim. Biophys. Acta. 1252 (1995) 305. doi: https://doi.org/10.1016/0167-4838(95)00126-F

28. Yan, J., Yang, J., Xu, L., Yan, Y., Gene cloning, over expression and characterization of a novel organic solvent tolerant and thermostable lipase from Galactomyces geotrichum Y05, J. Mol. Catal. B: Enz. 49 (2007) 28. doi: https://doi.org/10.1016/j.molcatb.2007.07.006

29. Fregolente, P. B. L., Fregolente, L. V., Maciel, M. R. W., Carvalho, $P$. O., Screening of microbial lipases and evaluation on their potential to produce glycerides with high gama linolenic acid concentration, Braz. J. Microbiol. 40 (2009) 747. doi: https://doi.org/10.1590/S1517-83822009000400004

30. Suprapta, D. N., Arai, K., Iwai, H., Some physiological properties of citrus and noncitrus races of Geotrichum candidum isolated from soil in Japan, Mycosci. 37(1996) 401. doi: https://doi.org/10.1007/BF02460996

31. Lessard, M.-H., Viel, C., Boyle, B., St-Gelais, D., Labrie, S., Metatranscriptome analysis of fungal strains Penicillium camemberti and Geotrichum candidum reveal cheese matrix breakdown and potential development of sensory properties of ripened Camembert-type cheese, BMC Genomics. 15 (2014) 235. doi: https://10.1186/1471-2164-15-235

32. Marcellino, N., Beuvier, E., Grappin, R., Guéguen, M., Benson, D. R., Diversity of Geotrichum candidum strains isolated from traditional cheese making fabrications in France, Appl. Env. Microbiol. 67 (2001) 4752. doi: https://doi.org/10.1128/AEM.67.10.4752-4759.2001

33. Thornton, C. R., Slaughter, D. C., Davis, R. M., Detection of the sour-rot pathogen Geotrichum candidum in tomato fruit and juice by using a highly specific monoclonal antibody-based ELISA, Int. J. Food Microbiol. 143 (2010) 166. doi: https://doi.org/10.1016/j.ijfoodmicro.2010.08.012
34. Prakash, P. Y., Seetaramaiah, V. K., Thomas, J., Khanna, V., Rao, S. P., Renal fungal bezoar owing to Geotrichum candidum, Med. Mycol. Case Report. 1 (2012) 63. doi: https://doi.org/10.1016/j.mmcr.2012.08.001

35. Gente, S., Desmasures, N., Panoff, J.-M., Guéguen, M., Genetic diversity among Geotrichum candidum strains from various substrates studied using RAM and RAPD-PCR, J. Appl. Microbiol. 92 (2002) 491. doi: https://doi.org/10.1046/j.1365-2672.2002.01553.x

36. Damasceno, S., Cereda, M. P., Pastore, G. M., Oliveira, J. $G$., Production of volatile compounds by Geotrichum fragrans using cassava wastewater as substrate, Process Biochem. 39 (2003) 411. doi: https://doi.org/10.1016/S0032-9592(03)00097-9

37. Kaewwichian, R., Yongmanitchai, W., Srisuk, N., Fujiyama, $K$., Limtong, S., Geotrichum siamensis sp. nov. and Geotrichum phurueaensis sp. nov., two asexual arthroconidial yeast species isolated in Thailand, FEMS Yeast Res. 10 (2010) 214. doi: https://doi.org/10.1111/j.1567-1364.2009.00572.x

38. Zapata, A. D. Z., Voget, C. E., Primary isolation of Geotrichum klebahnii polygalacturonase by capturing with glass fiber microfilters, Proc. Biochem. 47 (2012) 1277. doi: https://doi.org/10.1016/j.procbio.2012.04.023

39. Kinoshita, H., Ota, Y., Concentration of docosahexaenoic acid from fish oils using Geotrichum sp. FO347-2, Biosc. Biotechnol. Biochem. 65 (2001) 1022. doi: https://doi.org/10.1271/bbb.65.1022

40. Salihu, A., Alam, Z., Abdul, Karima, M. I., Salleh, H. M., Lipase production: An insight in the utilization of renewable agricultural residues, Res. Conserv. Recycl. 58 (2012) 36. doi: https://doi.org/10.1016/j.resconrec.2011.10.007

41. Hlavsová, K., Zarevúcka, M., Wimmer, Z., Macková, M., Sovová, H., Geotrichum candidum 4013: Extracellular lipase versus cell-bound lipase from the single strain, J. Mol. Catal. B: Enz. 61 (2009) 188. doi: https://doi.org/10.1016/j.molcatb.2009.06.012

42. Ramos, E. Z., Miotti Júnior, R. H., de Castro, P. F., Tardioli, P. W., Mendes, A. A., Fernandéz-Lafuente, R., Hirata, D. B., Production and immobilization of Geotrichum candidum lipase via physical adsorption on eco-friendly support: Characterization of the catalytic properties in hydrolysis and esterification reactions, J. Mol. Catal. B: Enz. 118 (2015) 43. doi: https://doi.org/10.1016/j.molcatb.2015.05.009

43. Shimada, Y., Sugihara, A., Nagao, T., Tominaga, Y., Induction of Geotrichum candidum lipase by long-chain fatty acids, J. Ferment. Bioeng. 74 (1992) 77. doi: https://doi.org/10.1016/0922-338X(92)80004-3

44. Zarevúcka, M., Kejik, Z., Sarnan, D., Wimmer, Z., Demnerová, $K$., Enantioselective properties of induced lipases from Geotrichum, Enz. Microb. Technol. 37 (2005) 481. doi: https://doi.org/10.1016/j.enzimictec.2004.07.021

45. Brabcová, J., Zarevúcka, M., Macková, M., Differences in hydrolytic abilities of two crude lipases from Geotrichum candidum 4013, Yeast. 27 (2010) 1029. doi: https://doi.org/10.1002/yea.1812

46. Loo, J. L., Lai, O. M., Long, K., Ghazali, H. M., Fatty acid preference of mycelium-bound lipase from a locally isolated strain of Geotrichum candidum, World J. Microbiol. Biotechnol. 23 (2007) 1771. doi: https://doi.org/10.1007/s11274-007-9427-2

47. Sacristán, N., González, L., Castro, J. M., Fresno, J. M., Tornadijo, M. E., Technological characterization of Geotrichum candidum strains isolated from a traditional Spanish goats' milk cheese, Food Microbiol. 30 (2012) 260. doi: https://doi.org/10.1016/j.fm.2011.10.003 
48. Yan, J. Y., Yan, Y. J., Optimization for producing cell-bound lipase from Geotrichum sp. and synthesis of methyl oleate in microaqueous solvent, Appl. Microbiol. Biotechnol. 78 (2008) 431 .

doi: https://doi.org/10.1007/s00253-007-1331-z

49. Resende-Maldonado, R., Burkert, J. F. M., Aguiar-Oliveira E., Durrant, L., Mazutti, M. A., Maugeri Filho, F., Rodrigues, M. I., Elucidation of the effects of inoculum size and age on lipase production by Geotrichum candidum, Biotecnol. Aplic. 31 (2014)216.

50. Aldarf, M., Fourcade, F., Amrane, A., Solid-state culture of Geotrichum candidum and Penicillium camembertii on a glutamate and lactate based medium, Enz. Microb. Technol. 36 (2005) 159.

doi: https://doi.org/10.1016/j.enzmictec.2004.03.027

51. Asses, N., Ayed, L., Bouallagui, H., Rejeb, I. B., Gargouri, M., Hamdi, M., Use of Geotrichum candidum for olive mill wastewater treatment in submerged and static culture, Biores. Technol. 100 (2009) 2182 doi: https://doi.org/10.1016/j.biortech.2008.10.048

52. Burket, J. F. M., Maldonado, R. R., Maugeri, F., Rodrigues, M. I., Comparison of lipase production by Geotrichum candidum in stirring and airlift fermenters, J. Chem. Technol. Biotechnol. 80 (2005) 61.

doi: https://doi.org/10.1002/jctb. 1157

53. Maldonado, R. R., Aguiar-Oliveira, E., Pozza, E. L., Costa, F. A. A., Maugeri Filho, F., Rodrigues, M. I., Production of lipase from Geotrichum candidum using corn steep liquor in different bioreactors, J. Am. Oil Chem. Soc. 91 (2014) 1999. doi: https://doi.org/10.1007/s11746-014-2552-9

54. Maldonado, R. R., Macedo, G. A., Rodrigues, M. I., Lipase production using microorganisms from different agro-industrial byproducts, Int. J. Appl. Sci. Technol. 4 (2014) 108.

55. Adour, L., Bude, F., Amrane, A., Sequential use of ammonium and leucine as nitrogen sources during growth of Geotrichum candidum on a glucose based medium, Electron. J. Biotechnol. 13 (2010). doi: https://doi.org/10.2225/vol13-issue1-fulltext-5

56. Burket, J. F. M., Maugeri, F., Rodrigues, M. I., Optimization of extracellular lipase production by Geotrichum sp. using factorial design, Biores. Techonol. 91 (2004) 77. doi: https://doi.org/10.1016/S0960-8524(03)00152-4

57. Ginalska, G., Chio, H. Y., Cho, N. S., Bancerz, R., Komilowicz, T., Leonowicz, A., Oga, S., Effect of culture conditions on growth and lipase production by a newly isolated strain, Geotrichum-like R59 (Basidiomycetes), J. Faculty Agricult. 52 (2007)29.

58. Gopinath, S. C. B., Hilda, A., Lakshmi priya, T., Annadurai, G., Anbu, P., Purification of lipase from Geotrichum candidum: conditions optimized for enzyme production using Box-Behnken design, World J. Microbiol. Biotechnol. 19 (2003) 681. doi: https://doi.org/10.1023/A:1025119222925

59. Loo, J. L., Lai, O. M., Long, K., Ghazali, H. M., Identification and characterisation of a locally isolated lipolytic microfungus - Geotrichum candidum, Malays. J. Microbiol. 2 (2006) 22.

60. Maldonado, R. R., Aguiar-Oliveira, E., Pozza, E. L., Costa, F. A. A., Mazutti, M. A., Maugeri, F., Rodrigues, M. I., Application of yeast hydrolysate in extracellular lipase production by Geotrichum candidum in shaken flasks, stirred tank, and air lift reactors, Can. J. Chem. Eng. 93 (2015) 1524.

doi: https://doi.org/10.1002/cjce. 22260
61. Maldonado, R. R., Burkert, J. F. M., Mazutti, M. A. Maugeri, F., Rodrigues, M. I., Evaluation of lipase production by Geotrichum candidum in shaken flasks and benchscale stirred bioreactor using different impellers, Biocatal. Agricult. Biotechnol. 1 (2012) 147. doi: https://doi.org/10.1016/j.bcab.2012.01.003

62. Maldonado, R. R., Panciera, A. L., Macedo, G. A., Mazutti, M. A., Maugeri, F., Rodrigues, M. I., Improvement of lipase production from Geotrichum sp. in shaken flasks, Chem. Ind. Chem. Eng. Quart. 18 (2012) 459. doi: https://doi.org/10.2298/CICEQ120124022M

63. Mladenoska, I., Isolation and purification of lipases from Geotrichum Candidum grown on a sunflower oil waste as a carbon source, Chem. Eng. Trans. 42 (2014) 49 doi: https://doi.org/10.3303/CET1442009

64. de Morais, W. G., Kamimura, E. S., Ribeiro, E. J. Pessela, B. C., Cardoso, V. L., de Resende, M. M., Optimization of the production and characterization of lipase from Candida rugosa and Geotrichum candidum in soybean molasses by submerged fermentation, Prot. Exp. Purif. 123 (2016) 26. doi: https://doi.org/10.1016/j.pep.2016.04.001

65. Mughal, M. S., Ali, S., Ashiq, M., Talish, A. S., Kinetics of an extracellular exo-inulinase production from a 5-flourocytosine resistant mutant of Geotrichum candidum using two-factorial design, Biores. Technol. 100 (2009) 3657 . doi: https://doi.org/10.1016/j.biortech.2009.01.051

66. Tsujisaka, Y., Iwai, M., Fukumoto, J., Okamoto, Y., Induced formation of lipase by Geotrichum candidum Link, Agr. BioI. Chem. 37 (1973) 837. doi: https://doi.org/10.1080/00021369.1973.10860759

67. Cao, Y., Yao, J., Li, J., Chen, X., Wu, J., Breeding of high lipid producing strain of Geotrichum robustum by ion beam implantation, Electr. J. Biotechnol. 13 (2010). doi: https://doi.org/10.2225/vol13-issue6-fulltext-4

68. Yan, J., Yang, J., Xu, L., Yan, Y., Cloning and overexpression of lipase gene from Geotrichum candidum Y162, Acta Microbiol. Sinica. 2 (2008) 184

69. Pan, X.-X., Xu, L., Zhang, Y., Xiao, X., Wang, X.-F., Liu, Y., Zhang, H.-J., Yan, Y.-J., Efficient display of active Geotrichum sp. lipase on Pichia pastoris cell wall and its application as a whole-cell biocatalyst to enrich EPA and DHA in fish oil, J. Agricult. FoodChem. 60 (2012) 9673. doi: https://doi.org/10.1021/jf301827y

70. Fernández, L., Pérez-Victoria, I., Zafra, A., Benitez, P. L., Morales, J. C., Velasco, J., Adrio, J. L., High-level expression and characterization of Galactomyces geotrichum (BT107) lipase I in Pichia pastoris, Prot. Exp. Purific. 49 (2006) 256. doi: https://doi.org/10.1016/j.pep.2006.06.015

71. Ginalska, G., Bancerz, R., Kornillowicz-Kowalska, $T$., A thermostable lipase produced by a newly isolated Geotrichum-like strain, R59, J. Indust. Microbiol. Biotechnol. 31 (2004) 177. doi: https://doi.org/10.1007/s10295-004-0134-9

72. Asahara, T., Matori, M., Ikemoto, M., Ota, Y., Production of two types of lipases with opposite positional specificity by Geotrichum sp. F0401B, Biosci. Biotech. Biochem. 57 (1993) 390. doi: https://doi.org/ 10.1271/bbb.57.390

73. Ota, Y., Sawamoto, T., Hasuo, M., Tributyrin specifically induces a lipase with a preference for the sn-2 position of triglyceride in Geotrichum sp. FO401B, Biosc. Biotechnol. Biochem. 64 (2000) 2497. doi: https://doi.org/10.1271/bbb.64.2497 
74. Bertolini, M. C., Laramee, L., Thomas, D. Y., Cygler, M., Schrag, J. D., Vernet, T., Expression and characterization of Geotrichum candidum lipase I gene: comparison of specificity profile with lipase I1, Eur. J. Biochem. 219 (1994) 119. doi: https://doi.org/10.1111/j.1432-1033.1994.tb19921.x

75. Charton, E., Macrae, A. R., Substrate specificities of lipases A and B from Geotrichum candidum CMICC 335426, Biochim. Bioph. Acta. 1123 (1992) 59. doi: https://doi.org/10.1016/0005-2760(92)90171-Q

76. Stránský, K., Zarevúcka, M., Kejík, Z., Wimmer, Z., Macková, M., Demnerová, K., Substrate specificity, regioselectivity and hydrolytic activity of lipases activated from $\mathrm{Geo}$ trichum sp., Biochem. Eng. J. 34 (2007) 209. doi: https://doi.org/10.1016/j.bej.2006.12.006

77. Veeraragavan, K., Colpitts, T., Gibbs, B. F., Purification and characterization of two distinct lipases from $\mathrm{Geo}$ trichum candidum, Biochim. Biophys. Acta. 1044 (1990) 26.

doi: https://doi.org/10.1016/0005-2760(90)90214-I

78. Maldonado, R. R., Aguiar-Oliveira, E., Fogaça, F. M., Ramos, G. G., Macedo, G. A., Rodrigues, M. I., Evaluation of partial purification and immobilization of lipase from Geotrichum candidum, Biocatal. Agricult. Biotechnol. 4 (2015) 321. doi: https://doi.org/10.1016/j.bcab.2015.05.005

79. Cai, Y., Wang, L., Liao, X., Ding, Y., Purification and partial characterization of two new cold-adapted lipases from mesophilic Geotrichum sp. SYBC WU-3, J. Process Biochem. 44 (2009) 786. doi: https://doi.org/10.1016/j.procbio.2009.03.011

80. Xu, L., Pan, X.-X., Liu, W.-S., Shen, X.-G., Wang, X.-F., Liu, Y., Yan, Y.-J., Preparation of a promising whole cell biocatalyst of Geotrichum sp. lipase and its properties, J. Chem. Technol. Biotechnol. 87 (2012) 498. doi: https://doi.org/10.1002/jctb. 2736

81. Brabcová, J., Demianová, Z., Vondrášek, J., Jágr, M., Zarevúcka, M., Palomo, J. M., Highly selective purification of three lipases from Geotrichum candidum 4013 and their characterization and biotechnological applications, J. Mol. Catal. B: Enz. 98 (2013) 62. doi: https://doi.org/10.1016/j.molcatb.2013.09.012

82. Huang, Y., Locy, R., Weete, J. D., Purification and characterization of an extracellular lipase from Geotrichum marinum, Lipids 39 (2004) 251. doi: https://doi.org/10.1007/s11745-004-1227-1

83. Jacobsen, T., Olsen, J., Allermann, K., Poulsen, O. M., $\mathrm{Hau}, \mathrm{J}$., Production, partial purification, and immunochemical characterization of multiple forms of lipase from $\mathrm{GeO}$ trichum candidum, Enz. Microbial. Technol. 11 (1989) 90. doi: https://doi.org/10.1016/0141-0229(89)90066-5

84. Mazzeu, C. J., Ramos, E. Z., Cavalcanti, M. H. S., Hirata, D. B., Virtuoso, L. S., Partitioning of Geotrichum candidum Lipase from fermentative crude extract by aqueous twophase system of polyethylene glycol and sodium citrate, Sep. Purif. Technol. 156 (2015) 158. doi: https://doi.org/10.1016/j.seppur.2015.09.069

85. Mendieta-Taboata, O., Kamimura, E. S., Maugeri, F., Modelling and simulation of the adsorption of the lipase from Geotrichum sp. on hydrophobic interaction columns, Biotechnol. Lett. 23 (2001) 781. doi: https://doi.org/10.1023/A:1010302416897

86. Tsujisaka, Y., Iwai, M., Tominaga, Y., Purification, crystallization and some properties of lipase from Geotrichum candidum Link, Agr. Biol. Chem. 37 (1973) 1457. doi: https://doi.org/10.1080/00021369.1973.10860854
87. Holmquist, M., Tessier, D. C., Cygler, M., High-level production of recombinant Geotrichum candidum lipases in yeast Pichia pastoris, Prot. Expr. Purific. 11 (1997) 35. doi: https://doi.org/10.1006/prep.1997.0747.

88. Saxena, R. K., Sheoran, A., Giri, B., Davidson, W. S., Purification strategies for microbial lipases, J. Microbiol. Methods. 52 (2003) 1. doi: https://doi.org/10.1016/S0167-7012(02)00161-6.

89. Hedrich, H. C., Spenser, F., Menge, U., Hecht, H.-J., Schmid, $R$. D., Large-scale purification, enzymic characterization, and crystallization of the lipase from Geotrichum candidum, Enz. Microbial. Technol. 13 (1991) 840.

doi: https://doi.org/10.1016/0141-0229(91)90069-M.

90. Tahoun, M. K., Fatty acid and position specificities of an intracellular lipase from Geotrichum candidum, Eur. J. Lipid. Sci. Technol. 89 (1978) 318 doi: https://doi.org/10.1002/lipi.19870890807.

91. Sugihara, A., Shimada, Y., Nakamura, M., Nagao, T., Tominaga, Y., Positional and fatty acid specificities of Geotrichum candidum lipase, Prot. Eng. 7 (1994) 585. doi: https://doi.org/10.1093/protein/7.4.585.

92. Baillargeon, W. W., McCarthy, S. G., Geotrichum candidum NRRL Y-553 lipase. Purification, characterization and fatty acid specificity, Lipids 26 (1991) 831. doi: https://doi.org/10.1007/BF02536165.

93. Okumura, S., Iwai, M., Tsujisaka, Y., The effect of reverse action on triglyceride hydrolysis by lipase, Agric. Biol. Chem. 45 (1981) 185. doi: https://doi.org/10.1080/00021369.1981.10864483.

94. Jacobsen, T., Poulsen, O. M., Separation and characterization of 61 - and $57-\mathrm{kDa}$ lipases from Geotrichum candidum ATCC 66592, Canad. J. Microbiol. 38 (1992) 75. doi: https://doi.org/10.1139/m92-012.

95. Phillips, A., Pretorius, G. H. J., Purification and characterization of an extracellular lipase of Galactomyces geotrichum, Biotechnol. Lett. 13 (1991) 833. doi: https://doi.org/10.1007/BF01026769.

96. Bertolini, M. C., Schrag, J. D., Cygler, M., Ziomek, E., Thomas, D. Y., Vernet, T., Polymorphism in the lipase genes of Geotrichum candidum strains, Eur. J. Biochem. 228 (1995) 863. doi: https://doi.org/10.1111/j.1432-1033.1995.0863m.x.

97. Maldonado, R. R., Pozza, E. L., Aguiar-Oliveira, E., Costa, F. A. A., Maugeri Filho, F., Rodrigues, M. I. Characterization of crude and partially purified lipase from Geotrichum candidum obtained with different nitrogen sources, J. Amer. Oil Chem. Soc. 93 (2016) 1355. doi: https://doi.org/10.1007/s11746-016-2875-9.

98. Singh, A. K., Mukhopadhyay, M., Overview of fungal lipase: A review, Appl. Biochem. Biotechnol. 166 (2012) 486 . doi: https://doi.org/10.1007/s12010-011-9444-3.

99. Tan, T., Lu, J., Nie, K., Deng, L., Wang, F., Biodiesel production with immobilized lipase: A review, Biotechnol. Adv. 28 (2010) 628. doi: https://doi.org/10.1016/j.biotechadv.2010.05.012.

100. Villeneuve, P., Muderhwa, J. M., Graille, J., Haas, M. J., Customizing lipases for biocatalysis: A survey of chemical, physical and molecular biological approaches, J. Mol. Catal. B: Enz. 9 (2000) 113. doi: https://doi.org/10.1016/S1381-1177(99)00107-1.

101. Zhang, B., Weng, Y., Xu, H., Mao, Z., Enzyme immobilization for biodiesel production, Appl. Microbiol. Biotechnol. 93 (2012) 61 doi: https://doi.org/10.1007/s00253-011-3672-x. 
102. Yan, J., Liu, S., Hu, J., Gui, X., Wang, G., Yan, Y., Enzymatic enrichment of polyunsaturated fatty acids using novel lipase preparations modified by combination of immobilization and fish oil treatment, Biores. Technol. 102 (2011) 7154. doi: https://doi.org/10.1016/j.biortech.2011.04.065.

103. Yan, J., Gui, X., Wang, G., Yan, Y., Improving stability and activity of cross-linked enzyme aggregates based on polyethylenimine in hydrolysis of fish oil for enrichment of polyunsaturated fatty acids, Appl. Biochem. Biotechnol. 166 (2012) 925. doi: https://doi.org/10.1007/s12010-011-9480-z.

104. Yan, J., Yan, Y., Liu, S., Hu, J., Wang, G., Preparation of cross-linked lipase-coated micro-crystals for biodiesel production from waste cooking oil, Biores. Technol. 102 (2011) 4755. doi: https://doi.org/10.1016/j.biortech.2011.01.006.

105. Yan, J.-Y., Yan, Y.-J., Yang, J. K., Xu, L., Liu, Y., Combined strategy for preparation of a bioimprinted Geotrichum sp. lipase biocatalyst effective in non-aqueous media, Proc. Biochem. 44 (2009) 1128. doi: https://doi.org/10.1016/j.procbio.2009.06.008

106. Pan, B.-F., Dai, X., Li, Z.-Y., Ward, O. P., Silicone-immobilized cells of Geotrichum sp. G38 used in biotransformation, World J. Microbiol. Biotechnol. 13 (1997) 17. doi:https://doi.org/10.1007/BF02770801.

107. Bleve, G., Lezzi, C., Chiriatti, M. A., D'Ostuni, I., Tristezza, M., Di Venere, D., Sergio, L., Mita, G., Grieco, F., Selection of non-conventional yeasts and their use in immobilized form for the bioremediation of olive oil mil wastewaters, Biores. Technol. 102(2011) 982 doi: https://doi.org/10.1016/j.biortech.2010.09.059.

108. Carballeira, J. D., Álvarez, E., Sinisterra, J. V., Biotransformation of cyclohexanone using immobilized Geotrichum candidum NCYC49. Factors affecting the selectivity of the process, J. Mol. Catal. B: Enz. 28 (2004) 25. doi: https://doi.org/10.1016/j.molcatb.2004.01.009.

109. Nakamura, K., Inoue, Y., Matsuda, T., Misawa, I., Stereoselective oxidation and reduction by immobilized Geotrichum candidum in an organic solvent, J. Chem. Soc. Perkin. Transact. 1. 1 (1999) 2397. doi: https://doi.org/10.1039/A900936A.

110. Paiva, A. L., Balcão, V. M., Malcata, F. X., Kinetics and mechanisms of reactions catalyzed by immobilized lipases, Enz. Microb. Technol. 27 (2000) 187. doi: https://doi.org/10.1016/S0141-0229(00)00206-4.

111. Christensen, M. W., Andersen, L., Husum, T. L., Kirk, O., Industrial lipase immobilization, Eur. J. Lipid Sci. Technol. 105 (2003) 318 doi: https://doi.org/10.1002/ejlt.200390062.

112. Charton, E., Macrae, A. R., Specificities of immobilized Geotrichum candidum CMICC 335426 lipases A and B in hydrolysis and ester synthesis reactions in organic solvents, Enz. Microb. Technol. 15 (1993) 489. doi: https://doi.org/10.1016/0141-0229(93)90081-C.

113. Matsuda, T., Marukado, R., Mukouyama, M., Harada, T., Nakamura, K., Asymmetric reduction of ketones by Geotrichum candidum: immobilization and application to reactions using supercritical carbon dioxide, Tetrahed. Asym. 19 (2008) 2272. doi: https://doi.org/10.1016/j.tetasy.2008.09.018.

114. Sonnet, P. E., McNeill, G. P., Jun, W., Lipase of Geotrichum candidum immobilized on silica gel, J. Am. Oil Chem. Soc. 71 (1994) 1421. doi: https://doi.org/10.1007/BF02541366.
115. Bhattacharyya, M. S., Singh, A., Banerjee, U. C., Immobilization of intracellular carbonyl reductase from Geotrichum candidum for the stereoselective reduction of 1-naphthyl ketone, Biores. Technol. 101 (2010) 1581. doi: https://doi.org/10.1016/j.biortech.2009.09.080.

116. Ittrat, P., Chacho, T., Pholprayoon, J., Suttiwarayanon, N., Charoenpanich, J., Application of agriculture waste as a support for lipase immobilization, Biocatal. Agricult. Biotechnol. 3 (2014) 77. doi: https://doi.org/10.1016/j.bcab.2014.02.002.

117. Kuo, C.-H., Peng, L.-T., Kan, S.-C., Liu, Y.-C., Shieh, C.$J$., Lipase-immobilized biocatalytic membranes for biodiesel production, Biores. Technol. 145 (2013) 229 doi: https://doi.org/10.1016/j.biortech.2012.12.054.

118. Wu, Z., Qi, W., Wang, M., Su, R., He, Z., Lipase immobilized on novel ceramic supporter with $\mathrm{Ni}$ activation for efficient cinnamyl acetate synthesis, J. Mol. Catal. B Enz. 110 (2014) 32. doi: https://doi.org/10.1016/j.molcatb.2014.09.010

119. Xue-hui, D., Jun-mei, O., He, G., Qi, F., Immobilization and stability of lipase-producing strain Geotrichum candidum NS3, J. Food Sci. Biotechnol. 2 (2009) 224.

120. Ward, O. P., Singh, A., Omega-3/6 fatty acids: Alternative sources of production, Proc. Biochem. 40 (2005) 3627. doi: https://doi.org/10.1016/j.procbio.2005.02.020.

121. Foglia, T. A., Sonnet, P. E., Fatty acid selectivity of lipases: $\gamma$-linolenic acid from borage oil, J. Am. Oil Chem. Soc. 72 (1995) 417 doi: https://doi.org/10.1007/BF02636081.

122. Belury, M. A., Dietary conjugated linoleic acid in health physiological effects and mechanisms of action, Annual Rev. Nut. 22 (2002) 505. doi: https://doi.org/10.1146/annurev.nutr.22.021302.121842.

123. McNeill, G. P., Rawlins, C., Peilow, A. C., Enzymatic enrichment of conjugated linoleic acid isomers and incorporation into triglycerides, J. Am. Oil Chem. Soc. 76 (1999) 1265. doi: https://doi.org/10.1007/s11746-999-0137-9.

124. Haas, M. J., Kramer, J. K. G., McNeill, G., Scott, K., Foglia, T. A., Sehat, N., Fritsche, J., Mossoba, M. M., Yurawecz, M. P., Lipase-catalyzed fractionation of conjugated linoleic acid isomers, Lipids. 34 (1999) 979. doi: https://doi.org/10.1007/s11745-999-0448-7.

125. Diks, R. M. M., Lee, M. J., Production of a very low saturate oil based on the specificity of Geotrichum candidum lipase, J. Am. Oil Chem. Soc. 76 (1999) 455. doi: https://doi.org/10.1007/s11746-999-0024-4.

126. Aguedo, M., Ly, M. H., Belo, I., Teixeira, J. A., Belin, J.M., Waché, Y., The use of enzymes and microorganisms for the production of aroma compounds from lipids, Food Technol. Biotechnol. 42 (2004) 327.

127. Collins, Y. F., McSweeney, P. L. H., Wilkinson, M. G., Lipolysis and free fatty acid catabolism in cheese: a review of current knowledge, Int. Dairy J. 13 (2003) 841 doi: https://doi.org/10.1016/S0958-6946(03)00109-2.

128. Gaborit, P., Menard, A., Morgan, F., Impact of ripening strains on the typical flavour of goat cheeses, Int. Dairy J. 11 (2001) 315. doi: https://doi.org/10.1016/S0958-6946(01)00061-9.

129. Jollivet, N., Chataud, J., Vayssier, Y., Bensoussan, M., Belin, J. M., Production of volatile compounds in model milk and cheese media by eight strains of Geotrichum candidum link, J. Dairy Res. 61 (1994) 241. doi: https://doi.org/10.1017/S0022029900028259. 
130. Neto, R. S., Pastore, G. M., Macedo, G. A., Biocatalysis and biotransformation producing $\gamma$-decalactone, J. Food Sci. 69 (2004) C677. doi: https://doi.org/10.1111/j.1365-2621.2004.tb09914.x

131. Macedo, G. A., Pastore, G. M., Lipases biocatalysis in the production of flavor esters, Ciência Tecnol. Aliment. 17 (1997) 115.

doi: https://doi.org/10.1590/S0101-20611997000200010
132. Vong, W. C., Liu, S. Q., Changes in volatile profile of soybean residue (okara) upon solid-state fermentation by yeasts, J. Sci. Food and Agric. Published online. doi: https://doi.org/10.1002/jsfa. 7700 